\title{
Editorial
}

\section{Management and monitoring of deep-sea fisheries and stocks}

\author{
Pascal Lorance ${ }^{\mathrm{a}}$
}

The management and monitoring of deep-sea fisheries and stocks is challenging due to the diversity of life histories in exploited stocks and sparseness of biological knowledge about certain species. Moreover, these issues are often combined with a relative shortage of suitable data. The FAO defines deep-sea fisheries as those exploiting species that can only sustain low exploitation rates (FAO 2009). In the European Union (EU) deep-sea fisheries are covered by council regulation No. 2347/2002 on "establishing specific access requirements and associated conditions applicable to fishing for deepsea stocks", which lists 24 species, including many deepwater sharks. Other definitions are used in other jurisdictions around the world.

The papers presented in this special issue address a number of questions relevant to assess deepwater stocks and moving towards an ecosystem approach to the management of European deepwater fisheries. The underlying research was carried out in the EU-funded Deepfishman project, "Management and Monitoring of Deep-sea Fisheries and Stocks" (Grant agreement No. 227390), which was conducted from 2009 to 2012. These papers complement a number of recently published studies on deepwater stocks and fisheries, many of which were part of the same project.

A recent review of deepwater stocks and their management worldwide concluded that, although deepwater fisheries in different regions might exploit the same species, case-specific monitoring and management strategies are often necessary (Large et al. 2013). Furthermore, Edwards et al. (2012) suggested that, although a range of approaches exist for deepwater stock assessment, from very simple to more sophisticated and informative, some methodological developments are still required. A recent example of such a development is the statistical catch-at-age model, which was used to assess the recruitment strength of the beaked redfish, Sebastes mentella in the Barents Sea (Planque et al. 2012). Another statistical catch-atage model was developed to provide estimates of total mortality and abundance of blue ling, Molva dypterygia, to the west of the British Isles (Trenkel et al. 2012). This model makes stock assessments possible using only fishery-dependent data

${ }^{a}$ pascal.lorance@ifremer.fr (total removals and catch-at-age in number) without requiring fishery-independent data (e.g., survey indices). Complementing these new assessment models, the paper by Figueiredo et al. (2013) proposes a Bayesian state space model for the assessment of the deepwater shark Centroscymnus coelolepis. The modelling approach developed by Figueiredo et al. might also be suitable for other species: other deepwater sharks in particular, but also the elasmobranchs as a whole, for which some knowledge of the life history is available but catch data are often uncertain. A similar modelling approach is under development for assessing black scabbardfish, Aphanopus carbo. Black scabbardfish is exploited in distinct locations to the west of the British Isles, off Portugal and around the Azores, but may form one single population in the northeast Atlantic (Farias et al. 2013).

Owing to data limitations, quantitative population modelling is not feasible for all exploited stocks. Although this fact is often stated for stocks exploited by deepwater fisheries, it is also true for many bycatch species, such as sharks and rays. Simpler alternatives are therefore required to assess the status and/or the risk exposure of populations that cannot be assessed by the usual fisheries science approaches (Le Quesne and Jennings 2012). Dransfeld et al. (2013) used the productivitysusceptibility analysis (PSA) method to appraise the biological vulnerability of orange roughy, Hoplostethus atlanticus, and the risk that fisheries impose on its populations compared with other deepwater species. The study suggested that orange roughy is relatively less vulnerable than deepwater sharks to the impact of existing fisheries. Furthermore, a smaller bodied finfish species included in the analysis, the Atlantic codling, Lepidion eques, was found to be less vulnerable than larger commercial species. This result agrees with the postulate that "fishing fleets generate a fishing mortality on non-target species which is less than or equal to that generated on target species" and that life-history characteristics of smaller species allow them to sustain higher fishing mortality (Jennings 2013; Pope et al. 2000).

Although deepwater fisheries are often perceived as "datapoor", the amount of data available can be significant, in particular when drawing on information collected by the fishing industry. Thus, it was possible to apply spatial approaches, 
which are generally considered data-consuming Trenkel et al. (2013) performed simulation testing of spatial indicators derived from EU-logbooks for the four main deepwater stocks exploited to the west of the British Isles. Veiga et al. (2013) assessed the spatial overlap between catches of deepwater sharks and black scabbardfish to the west of Portugal using logbook and EU vessel monitoring system (VMS) data. Lastly, Burgos et al. (2013) assessed the fishing effort and its spatial distribution over time in the small-scale fishery for the blackspot seabream, Pagellus bogaraveo, in the Strait of Gibraltar using a regional VMS data based upon the GPRS/GSM mobile phone network; this technology could substantially improve the monitoring of fishing effort in small-scale fisheries.

Planque et al. (2013) described the complexity of monitoring requirements for beaked redfish fisheries. Although this species may represent a somewhat extreme case of complexity due to its wide geographic distribution, meta-population structure, issues with age estimation, migrations and interactions with the environment and the pelagic ecosystem, Planque et al. show that solutions exist for monitoring future changes in beaked redfish stocks.

Garcia et al. (2013) carried out management strategy evaluation (MSE) of three different fisheries and tested a number of management scenarios. The authors discuss which further simulations would be needed to make the results realistic, in particular in a mixed-fisheries context.

Tsagarakis et al. (2013) studied temporal variations in the deepwater fish communities of the eastern Ionian Sea and concluded that fish communities are improving following a period of fishing reduction. The improvement involved several taxonomic groups including those sensitive to fishing such as Chondrichthyes.

Although it represents a greater challenge, the assessment, management and monitoring of deepwater fisheries did not appear to be intrinsically different from shelf fisheries. The main remaining need for research is most probably the combination of fisheries management measures at population and community levels, with the spatial management required to protect vulnerable marine ecosystems (VME), such as cold-water corals. Such management does not only concern deepwater fisheries, as cold-water corals occur as shallow as $100 \mathrm{~m}$ in European waters (e.g., Roberts et al. 2009) and even shallower in more boreal areas. Evaluating the trade-off between the exploitation of target populations at levels corresponding to their maximum sustainable yield (MSY) and ecosystem conservation probably requires an estimation of minimum spatial areas, i.e., the footprint fisheries need to operate on. As most deepwater fish species are (highly) mobile, it seems conceivable that they could be fully exploited by only fishing a small proportion of the seabed compared to less mobile species living in shallower areas closer to the coast. When older and larger individuals are found deeper than younger fish, as observed for hake, monkfish and some deepwater species, restricting fishing to deeper waters may be beneficial (Edwards and Plaganyi 2011). The question of minimising the footprint of fisheries across several target species is complex and should be addressed in dedicated studies.

\section{References}

Burgos C., Gil J., del Olmo L.A., 2013, The Spanish blackspot seabream (Pagellus bogaraveo) fishery in the Strait of Gibraltar: spatial distribution and fishing effort derived from a small-scale GPRS/GSM based fisheries vessel monitoring system. Aquat. Living Resour. 26, 399-407.

Dransfeld L., Gerritsen H.D., Hareide N.R., Lorance P., 2013, Assessing the risk of vulnerable species exposure to deepwater trawl fisheries: the case of orange roughy Hoplostethus atlanticus to the west of Ireland and Britain. Aquat. Living Resour. 26, 307-318.

Edwards C.T.T., Hillary R.M., Levontin P., Blanchard J.L., Lorenzen K., 2012, Fisheries assessment and management: a synthesis of common approaches with special reference to deepwater and data-poor stocks. Rev. Fish. Sci. 20, 136-153.

Edwards C.T.T., Plaganyi E.E., 2011, Protecting old fish through spatial management: is there a benefit for sustainable exploitation? J. Appl. Ecol. 48, 853-863.

FAO, 2009, Deep-sea fisheries in the high seas. Ensuring sustainable use of marine resources and the protection of vulnerable marine ecosystems. FAO Report, Rome, 12 p.

Farias I., Morales-Nin B., Lorance P., Figueiredo I., 2013, Black scabbardfish, Aphanopus carbo, in the northeast Atlantic: distribution and hypothetical migratory cycle. Aquat. Living Resour. 26, 333-342.

Figueiredo I., Natario I., Moura T., Carvalho L., 2013, Modelling the dynamics of the deepwater shark Centroscymnus coelolepis off mainland Portugal. Aquat. Living Resour. 26, 355-364.

Garcia G., Urtizberea A., Diez G., Gil J., Marchal P., 2013, Bioeconomic management strategy evaluation of deepwater stocks using the FLBEIA model. Aquat. Living Resour. 26, 365-379.

Jennings S., 2013. When can principles support advice on fisheries and environmental management? ICES J. Mar. Sci. 70, 726-733.

Large P.A., Agnew D.J., Pérez J.A.A., Barrio Froján C., Cloete R., Damalas D., Dransfield L., Edwards C.T.T., Feist S., Figueiredo I., González F., Gil-Herrera J., Kenny A., Jakobsdóttir K., Longshaw M., Lorance P., Marchal P., Mytilineou C., Planque B., Politou C.Y., 2013, Strengths and weaknesses of the management and monitoring of deep-water stocks, fisheries and ecosystems in various areas of the world - a roadmap towards sustainable deep-water fisheries in the Northeast Atlantic? Rev. Fish. Sci. 21, 157-180.

Le Quesne W.J.F., Jennings S., 2012, Predicting species vulnerability with minimal data to support rapid risk assessment of fishing impacts on biodiversity. J. Appl. Ecol. 49, 20-28.

Planque B., Johannesen E., Drevetnyak K.V., Nedreaas K.H., 2012, Historical variations in the year-class strength of beaked redfish (Sebastes mentella) in the Barents Sea. ICES J. Mar. Sci. 69, $547-552$.

Planque B., Kristinsson K., Astakhov A., Bernreuther M., Bethke E., Drevetnyak K., Nedreaas K., Reinert J., Rolskiy A., Sigurðsson T., Stransky C., 2013, Monitoring beaked redfish (Sebastes mentella) in the North Atlantic, current challenges and future prospects. Aquat. Living Resour. 26, 293-306.

Pope J.G., MacDonald D.S., Daan N., Reynolds J.D., Jennings S., 2000, Gauging the impact of fishing mortality on non-target species. ICES J. Mar. Sci. 57, 689-696.

Roberts J.M., Davies A.J., Henry L.A., Dodds L.A., Duineveld G.C.A., Lavaleye M.S.S., Maier C., van Soest R.W.M., Bergman M.J.N., Huehnerbach V., Huvenne V.A.I., Sinclair D.J., Watmough T., Long D., Green S.L., van Haren H., 2009, Mingulay reef complex: an interdisciplinary study of cold-water 
coral habitat, hydrography and biodiversity. Mar. Ecol. Prog. Ser. 397, 139-151.

Trenkel V.M., Beecham J.A., Blanchard J.L., Edwards C.T.T., Lorance P., 2013, Testing CPUE-derived spatial occupancy as an indicator for stock abundance: application to deep-sea stocks. Aquat. Living Resour. 26, 319-332.

Trenkel V.M., Bravington M.V., Lorance P., 2012, A random effects population dynamics model based on proportion-at-age and removal data for estimating total mortality. Can. J. Fish. Aquat. Sci. 69, 1881-1893.
Tsagarakis K., Mytilineou C., Haralabous J., Lorance P., Politou C.-Y., Dokos J., 2013, Mesoscale spatio-temporal dynamics of demersal assemblages of the Eastern Ionian Sea in relationship with natural and fisheries factors. Aquat. Living Resour. 26, 381397.

Veiga N., Moura T., Figueiredo I., 2013, Spatial overlap between the leafscale gulper shark and the black scabbardfish off Portugal. Aquat. Living Resour. 26, 343-353. 